\title{
Evaluasi kualitas, kuantitas telur dan larva ikan patin siam (Pangasianodon hiphopthalmus) dengan penambahan ovaprim dosis berbeda
}

\section{(Evaluation of quality, quantity of fish eggs, and larvae patin siam Pangasianodon hiphopthalmus injected with ovaprim at different doses)}

Vina O. Manantung, Hengky J. Sinjal, Revol Monijung

\begin{abstract}
This study was conducted to determine the effect of different doses of ovaprim on latency time of spawning, hatching rate, and survival of fish larvae (Pangasianodon hiphopthalmus). Experimental design used was Randomized Complete Design (CRD) with four treatments, each with three replication. The treatments including $0 \mathrm{ml}, 0.3 \mathrm{ml}, 0.6 \mathrm{ml}$ and $0.9 \mathrm{ml}$ ovaprim per $\mathrm{kg}$ of body weight of fish. Data collected consisted of latency time of spawning, hatching rate, and survival rate of larvae. The results showed that treatment with different doses of ovaprim hormones resulted in a significant influence on latency time of spawning, egg hatchability and survival rate of larvae. It was found that $0.6 \mathrm{ml}$ ovaprim could increase the latency time of spawning, egg hatchability and survival rate of larvae. The average latency time of larvae was 529 minutes, hatching rate was $80,86 \%$ and survival rate of larvae was $83,33 \%$.
\end{abstract}

Keywords : Pangasianodon hipophthalmus. Ovaprim, spawning time, hatching rate, survival rate

\section{PENDAHULUAN}

Ikan Patin Siam (Pangasianodon hypophthalmus) merupakan salah satu komoditas yang sukses dibudidayakan, baik pembenihan maupun pembesaran. Di Indonesia kehadiran ikan Patin Siam membawa dampak yang baik dalam membangkitkan usaha para pembudidaya ikan khususnya di daerah Sulawesi Utara. Meskipun pada saat ini teknologi pembenihan ikan Patin Siam telah berhasil dilakukan oleh BBAT Tatelu, namun untuk produksi dan kebutuhan larva bagi para pengusaha ikan di Daerah Sulawesi Utara belum dapat terpenuhi secara maksimal.

Keinginan masyarakat yang cukup tinggi untuk membudidayakan ikan Patin Siam belum terlayani sepenuhnya karena terbentur pada penyediaan benih yang terbatas. Sedangkan dalam kegiatan pembenihan ikan Patin Siam yaitu dari proses pemijahan sampai menghasilkan larva sangat diperlukan keterampilan, pengetahuan dan ketekunan. Banyak faktor yang harus diperhatikan dalam keberhasilan 
pembenihan ikan Patin Siam. Bagi seorang pembudidaya hal yang harus diperhatikan dalam keberhasilan usaha pembenihan ikan Patin Siam adalah teknik pembenihannya seperti pemilihan (seleksi) induk, melakukan penyuntikan sampai menghasilkan larva dan memeliharanya dengan tingkat kelangsungan hidup yang tinggi.

Salah satu upaya yang dapat dilakukan adalah dengan menambahkan atau menyuntikkan hormon ovaprim ke dalam tubuh ikan yang sudah matang gonad untuk mempercepat proses pemijahan sehingga dapat dihasilkan benih ikan Patin Siam yang baik dimana jumlah, mutu dan waktu penyediaannya dapat diatur sesuai yang diinginkan (Djarijah, 2001).

Ovaprim adalah campuran analog salmon Gonadotropihin Releasing Hormon (sGnRH-a) dan anti dopamine. Ovaprim adalah hormon yang berfungsi untuk merangsang dan memacu hormon gonadothropin pada tubuh ikan sehingga dapat mempercepat proses ovulasi dan pemijahan, yaitu pada proses pematangan gonad dan dapat memberikan daya rangsang yang lebih tinggi. Selain itu menghasilkan telur dengan kualitas yang baik serta menghasilkan waktu laten yang relatif singkat juga dapat menekan angka mortalitas (Sukendi, 1995). Hormon ini juga dapat bekerja pada organ target yang lebih tinggi pada ikan (Harker, 1992).

Untuk itu telah dilakukan penelitian dengan judul "Evalusi kualitas, kuantitas telur dan larva ikan patin siam (Pangasianodon hipophthalmus) dengan penambahan ovaprim pada tingkat dosis yang berbeda". Penelitian ini bertujuan untuk mengetahui apakah pemberian ovaprim dengan dosis yang berbeda dapat mempengaruhi latensi waktu pemijahan, daya tetas telur, dan kelangsungan hidup larva ikan Patin siam.

\section{BAHAN DAN METODE}

\section{Persiapan Ikan Uji.}

Ikan uji yang digunakan dalam penelitian ini adalah induk ikan patin siam (Pangasianodon hipophthalmus) yang telah matang gonad (12 jantan dan 12 betina) yang berumur kurang lebih 1,5 tahun dengan kisaran bobot jantan dan betina per individu adalah 1,5 - $2 \mathrm{~kg}$ untuk diambil sperma dan telurnya. Ikan - ikan tersebut ditampung dalam bak penampungan selama 1 hari secara terpisah antara induk jantan dan induk betina sebelum dilakukan penyuntikkan dan pengurutan.

\section{Prosedur Percobaan}

Percobaan dirancang berdasarkan RAL (Rancangan Acak Lengkap) dengan 4 perlakuan yang masing - masing perlakuan diulang sebanyak 3 kali. Perlakuan yang dicobakan adalah sebagai berikut :

Perlakuan A : Dosis Ovaprim $0 \mathrm{ml} / \mathrm{kg}$ berat badan ikan

Perlakuan B : Dosis Ovaprim 0,3 ml/kg berat badan ikan

Perlakuan C : Dosis Ovaprim 0,6 ml/kg berat badan ikan

Perlakuan D : Dosis Ovaprim 0,9 ml/kg berat badan ikan

Penyuntikkan ovaprim dilakukan dengan cara : Sebelum ikan uji digunakan dalam penyuntikkan, induk ikan Patin siam 
baik jantan maupun betina yang telah matang gonad diberok selama satu hari didalam bak pemberokan secara terpisah, induk ditimbang terlebih dahulu untuk menentukan dosis ovaprim yang akan diberikan, setelah itu proses penyuntikkan dilakukan. Penyuntikkan menggunakan ovaprim dilakukan dibagian punggung secara intramuscular (didalam otot) (Khairuman dan Amri, 2008), dengan cara : induk Ikan Patin diletakkan dilantai, tutupi kepala induk Patin Siam betina dengan kain agar ikan tidak berontak dan terhindar dari patil. Suntik induk dibagian punggung dengan kemiringan jarum suntik $40-45^{\circ} \mathrm{C}$ dan kedalaman jarum suntik $\pm 1 \mathrm{~cm}$ atau disesuaikan dengan besar kecilnya tubuh ikan. Setelah ovaprim didorong masuk, jarum suntik dicabut lalu bekas suntik ditutup dengan jari sambil ditekan secara perlahan - lahan beberapa saat agar ovaprim tidak keluar. Penyuntikkan terhadap ikan uji dilakukan satu kali dengan dosis yang sudah ditetapkan, setelah itu induk ikan dimasukkan kembali didalam bak penampung dan dibiarkan sampai proses pengambilan telur melalui pengurutan.

\section{Pengambilan Sperma}

Pengambilan sperma dilakukan dengan cara : ambil induk jantan yang sudah matang gonad, ditampung didalam botol bersih di tambahkan sodium chloride $(\mathrm{NaCl})$ sebanyak $5 \mathrm{ml}$ agar sperma menjadi encer.

\section{Pengambilan Telur}

Pengeluaran telur atau striping dilakukan dengan cara: menyiapkan mangkok plastik yang bersih dan kering, bulu ayam, kain dan tisu; sesudah itu induk
Patin betina ditangkap menggunakan serok, keringkan tubuh induk dengan kain, bungkus induk dengan kain namun pada bagian perut dan lubang genital dibiarkan tidak tertutup, taruhlah mangkok plastik sebagai wadah penampung telur dibawah ikan yang diurut perutnya, urut bagian perut kearah lubang urogenital, telur yang keluar tertampung dalam mangkok, campurkan larutan sperma kedalam telur tadi, aduk hingga merata dengan bulu ayam, tambahkan air bersih dan steril secukupnya dan aduk hingga merata lagi agar pembuahan dapat terjadi dengan sempurna. Buanglah air perlahan-lahan agar telur yang ada tidak ikut terbuang.

\section{Latensi Waktu Pemijahan}

Latensi waktu pemijahan ikan Patin siam dihitung berdasarkan data yang diambil selama proses pemijahan berlangsung dengan cara menghitung selisih waktu dari penyuntikan sampai keluarnya telur atau ovulasi.

\section{Daya Tetas Telur}

Dalam menentukan tingkat penetasan telur data yang diperlukan adalah banyaknya telur yang menetas pada masin masing perlakuan. Telur dihitung 200 butir telur kemudian dimasukan kedalam loyang yang telah diberi aerator. Setelah itu telur diinkubasi sampai telur-telur tadi menetas, kemudian hitung telur yang menetas. Menurut Efrizal (1998) daya tetas telur dapat dihitung dengan persamaan :

$$
\operatorname{Hr}(\%)=\frac{\text { Jumlah telur menetas }}{\text { Jumlah telur sampel }} \times 100
$$




\section{Sintasan Larva}

Untuk menghitung sintasan larva Patin Siam, larva hasil penetasan diambil sebanyak 100 ekor sebagai sampel pada tiap - tiap perlakuan dan ulangan kemudian larva tersebut dipelihara selama empat belas hari (14 hari). Dalam masa pemeliharaan larva diberi makanan Artemia. Larva diamati setiap hari. Data yang diamati adalah berapa banyak larva yang hidup selama masa pemeliharaan 14 hari.

Sintasan larva ditentukan pada akhir percobaan. Menurut Murtidjo (2001) sintasan larva dapat dihitung berdasarkan rumus :

$$
\mathrm{Sr}=\frac{\mathrm{Nt}}{\mathrm{No}} \mathrm{X} 100 \%
$$

Keterangan :

$\mathrm{Sr}$ = Survival Rate (Sintasan)

$\mathrm{Nt}=$ Jumlah larva hidup pada akhir pengumpulan data

No $=$ Jumlah larva hidup pada awal pengumpulan data.

\section{Analisis Data}

Penelitian ini menggunakan Rancangan Acak Lengkap (RAL) dengan 4 perlakuan yang diulang sebanyak 3 kali. Perlakuan dalam penelitian ini menggunakan dosis ovaprim yang berbeda. parameter yang diukur adalah : Latensi waktu pemijahan, daya tetas telur dan sintasan hidup larva.

Data yang didapat kemudian dianalisis menggunakan analisis ragam dengan program JMP, kemudian dilanjutkan dengan uji BNT, (Steel and Torrie, 1991).

\section{HASIL DAN PEMBAHASAN}

\section{Waktu latensi pemijahan}

Dari hasil terlihat bahwa waktu latensi tercepat terdapat pada perlakuan $0,6 \mathrm{ml} / \mathrm{kg}$ berat badan ikan (529) dan terendah pada perlakuan $0 \mathrm{ml} / \mathrm{kg}$ berat badan ikan (1019 menit) Tabel 1 dan Gambar 1.

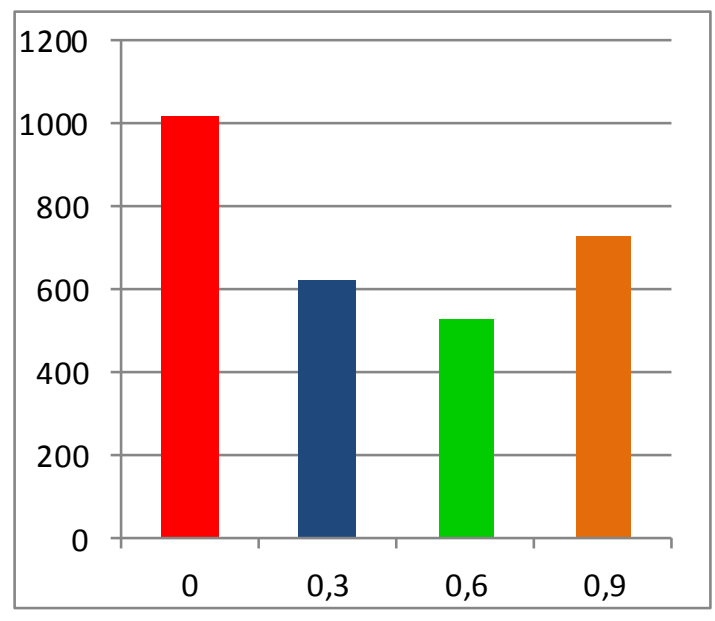

Perlakuan

Gambar 1. Waktu latensi pemijahan ikan patin siam dengan perlakuan dosis ovaprim berbeda

Berdasarkan analisis ragam diperoleh hasil bahwa perbedaan perlakuan dengan dosis ovaprim yang berbeda memberikan pengaruh yang sangat nyata terhadap perbedaan latensi waktu pemijahan ikan Patin siam.

Hasil analisis ragamyang diperoleh pada perlakuan $0,6 \mathrm{ml} / \mathrm{kg}$ berat badan ikan menunjukkan perbedaan sangat nyata dari perlakuan $0 \mathrm{ml} / \mathrm{kg}$ berat badan ikan, 0,3 $\mathrm{ml} / \mathrm{kg}$ berat badan ikan dan $0,9 \mathrm{ml} / \mathrm{kg}$ berat badan ikan (Tabel 1). 
Tabel 1. Analisis ragam waktu latensi pemijahan ikan patin siam dengan perlakuan dosis ovaprim yang berbeda.

\begin{tabular}{|c|c|c|c|c|c|c|}
\hline $\begin{array}{c}\text { Sumber } \\
\text { Keragaman }\end{array}$ & \multirow{2}{*}{$\mathrm{Db}$} & $\mathrm{Jk}$ & $\mathrm{Kt}$ & Fhitung & \multicolumn{2}{|c|}{$\mathrm{F}$ tabel } \\
\cline { 5 - 8 } & & & & & $5 \%$ & $1 \%$ \\
\hline Perlakuan & 3 & 402616,00 & 134205,33 & $23,55066^{* *}$ & 4,07 & 7,59 \\
\hline Galat & 8 & 45588,67 & 5698,58 & & & \\
\hline Total & 11 & 448204,67 & & & & \\
\hline
\end{tabular}

** Berbeda sangat nyata

Pemberian ovaprim pada ikan patin berdasarkan hasil percobaan ini menunjukkan bahwa pemberian ovaprim dengan dosis yang berbeda dapat mempengaruhi latensi waktu pemijahan. Waktu latensi yang diperlukan untuk matang telur (siap ovulasi) berbeda-beda pada setiap perlakuan.

Waktu latensi ditentukan dengan menghitung selisih waktu antara penyuntikan sampai keluarnya telur atau ovulasi. Hasil pengamatan terhadap waktu latensi setelah pemberian perlakuan pada ikan adalah pada perlakuan C (529 menit), perlakuan B (628 menit), perlakuan D (729 menit) dan perlakuan A (1019 menit). Dari hasil penelitian ini menunjukkan bahwa induk ikan Patin siam yang disuntik dengan dosis ovaprim $0,6 \mathrm{ml} / \mathrm{kg}$ berat badan ikan dapat menyebabkan peningkatan konsentrasi hormon gonadotropin didalam darah sehingga dapat merangsang perkembangan telur dan mempercepat proses pemijahan ikan dengan waktu latensi 529 menit. Sedangkan penyuntikkan ovaprim pada dosis $0,3 \mathrm{ml} / \mathrm{kg}$ berat badan ikan (628 menit) dan $0,9 \mathrm{ml} / \mathrm{kg}$ berat badan ikan (729 menit) tidak terlalu berpengaruh terhadap peningkatan gonadotropin. Menurut Fujaya (1999), induk ikan yang disuntik dengan hormon hipofisa, penyuntikkan hormon LHRH, dan lain - lain dapat menambah atau meningkatkan konsentrasi hormon gonadotropin dalam darah sehingga mampu menginduksi perkembangan telur dan pemijahan. Sedangkan induk ikan yang tidak diberikan dosis ovaprim akan terjadi kelambatan dalam proses pemijahan, hal ini dikarenakan kandungan gonadotropin dalam tubuh belum cukup untuk terjadinya ovulasi, dan tidak adanya rangsangan hormonal dari luar yang dapat meningkatkan kandungan gonadotropin dalam tubuh ikan (Fujaya F. 2004).

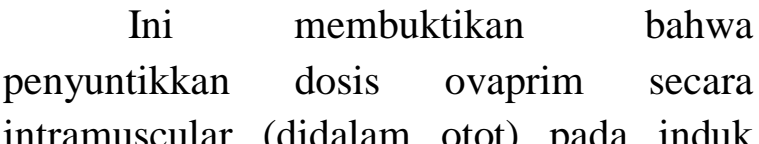
intramuscular (didalam otot) pada induk ikan Patin siam yang matang gonad dapat merangsang ovulasi. Dengan diperoleh waktu latensi yang tercepat pada perlakuan C dengan dosis ovaprim $0,6 \mathrm{ml} / \mathrm{kg}$ berat badan ikan, maka menunjukkan bahwa perlakuan tersebut merupakan yang berpotensi untuk merangsang terjadinya ovulasi. 
$\begin{array}{cccr}\text { Dari } & \text { uraian } & \text { diatas dapat } \\ \text { dikemukakan } & \text { bahwa penggunaan zat }\end{array}$ perangsang untuk mempersingkat waktu latensi terhadap ikan Patin siam (Pangasianodon hipophthalmus) betina yang matang gonad sangat bergantung pada dosis zat perangsang yang digunakan . kenyataan ini sesuai dengan yang dikemukakan oleh Epler (1981) bahwa $\mathrm{PGF}_{2} \alpha$ ini sangat berperan dalam kontaksi selaput folikel, dengan meningkatnya $\mathrm{PGF}_{2 \alpha}$ didalam darah akan meningkatkan kontraksi selaput folikel sehingga folikel dalam waktu yang lebih cepat akan berkontraksi dan terjadilah ovulasi. Ernawati (1990) mengemukakan bahwa pemberian $\mathrm{PGF}_{2} \alpha$ secara tunggal pada ikan Patin siam dapat memperkecil waktu latensi. Sedangkan Yuhsu dan Goetz (1991) menyatakan bahwa folikel sebelum ovulasi lebih banyak menghasilkan PGF daripada folikel sebelum GVBD pada ikan brook trout (Salvelinus fontinalis), yang berarti bahwa PGF sangat dibutuhkan pada saat akan terjadinya ovulasi.

Nandeesha et al, (1990) menyimpulkan bahwa kelebihan ovaprim bila dibandingkan dengan ekstrak hipofisa adalah : memberikan daya ransang pemijahan lebih tinggi, nilai fertilitas lebih tinggi, diameter telur lebih besar, waktu latensi lebih singkat dan angka mortalitas lebih rendah. Sedangkan prostaglandin merupakan bagian dari aksi gonadotropin pada saat ovulasi atau pecahnya folikel dan selanjutnya merangsang tingkah laku memijah pada ikan betina (Lam 1985). Peter at all, (1988) menyatakan bahwa beberapa kriteria untuk menilai efektifitas ovaprim ialah dengan melihat tinggi rendahnya tingkat keberhasilan pemijahan dan lama tidaknya interval waktu antara pemijahan dan penyuntikkan terakhir.

Dosis hormon yang digunakan dalam pemijahan ikan secara buatan menurut Woynarovich dan Horvarth (1981) tergantung kepada tingkat kematangan induk sedangkan jumlah dan pengaturan frekuensi penyuntikkan dengan memperhatikan tingkat kematangan induk betina.

Pengaruh larutan ovaprim dapat dilihat pada perbedaan antara yang disuntik dan yang tidak disuntik menggunakan hormon ovaprim. Induk ikan Patin siam yang disuntik dengan hormon ovaprim dosis $0,6 \mathrm{ml} / \mathrm{kg}$ berat badan ikan menunjukkan hasil yang baik dalam merangsang hormon gonadotropin untuk mempercepat proses pemijahan. Tapi ketika dosis ovaprim diturunkan menjadi $0,3 \mathrm{ml} / \mathrm{kg}$ berat badan ikan dan dinaikaan mnjadi $0,9 \mathrm{ml} / \mathrm{kg}$ berat badan ikan ternyata menunjukkan kecenderungan sudah kurang berpengaruh lagi terhadap latensi waktu pemijahan dikarenakan pemberian dosis ovaprim yang tidak sesuai. Sedangkan dosis ovaprim 0 $\mathrm{ml} / \mathrm{kg}$ berat badan ikan (tanpa perlakuan) menunjukkan bahwa tidak berpengaruh terhadap waktu latensi pemijahan dikarenakan tidak adanya rangsangan hormon yang diberikan dari luar yang dapat meningkatkan kandungan gonadotropin dalam tubuh ikan (Fujaya Y. 2004). Ini menyatakan bahwa perlakuan $0,6 \mathrm{ml} / \mathrm{kg}$ berat badan ikan ovaprim pada ikan mas yang digunakan sudah maksimum. Dengan demikian dapat dikatakan bahwa pemberian hormon ovaprim $0,6 \mathrm{ml} / \mathrm{kg}$ berat badan ikan dapat mempercepat proses pemijahan dan menghasilkan waktu latensi pemijahan yang 
cepat dengan rata - rata 529 menit setelah penyuntikkan.

Dari Uraian diatas dapat dikemukakan bahwa penggunaan zat perangsang untuk mempersingkat waktu laten terhadap ikan patin betina yang matang gonad sangat tergantung pada dosis ovaprim

\section{Daya tetas telur}

Dari hasil pengamatan yang dilakukan memperlihatkan bahwa daya tetas telur tertinggi terdapat pada perlakuan $0,6 \mathrm{ml}$ per kg berat badan ikan dan terendah pada perlakuan $0 \mathrm{ml} / \mathrm{kg}$ berat badan ikan (Gambar 2).

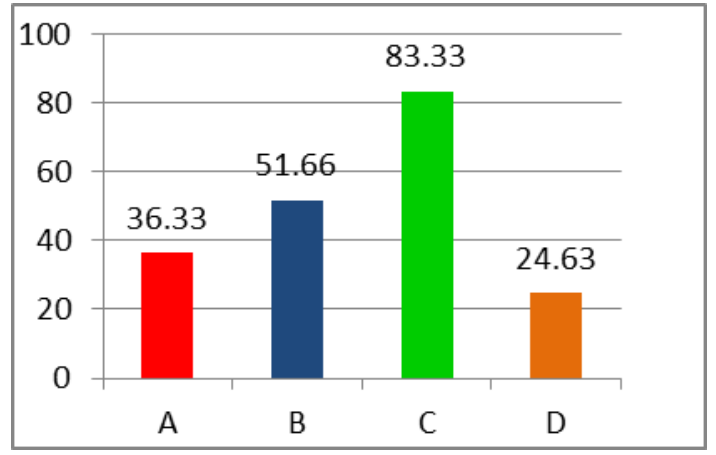

Perlakuan

Gambar 2. Daya tetas telur ikan patin siam gengan perlakuan dosis ovaprim berbeda.

Hasil analisis ragam yang diperoleh pada perlakuan 0,6 ml/kg berat badan ikan menunjukkan perbedaan sangat nyata dari perlakuan $0,3 \mathrm{ml} / \mathrm{kg}$ berat badan ikan, 0 $\mathrm{ml} / \mathrm{kg}$ berat badan ikan dan $0,9 \mathrm{ml} / \mathrm{kg}$ berat badan ikan..

Kualitas telur yang baik dapat juga dilihat dari daya tetas telur. Pemberian ovaprim mempengaruhi daya tetas ikan patin. Adanya korelasi positif antara peningkatan dosis ovaprim dengan peningkatan daya tetas telur dan mencapai puncak pada dosis tertentu. Untuk melihat pengaruh pemberian hormon ovaprim terhadap daya tetas telur pada ikan yang disuntik dengan hormon ovaprim dan yang tidak disuntik dengan hormon ovaprim ternyata terdapat perbedaan nilai persentase penetasan.

Induk ikan patin yang disuntik dengan hormon ovaprim dosis $0,6 \mathrm{ml} / \mathrm{kg}$ berat badan ikan menunjukkan hasil yang baik dalam merangsang hormon gonadotropin dalam mempercepat proses penetasan, tapi ketika dosis ovaprim diturunkan menjadi $0,3 \mathrm{ml} / \mathrm{kg}$ berat badan ikan dan dinaikan menjadi $0,9 \mathrm{ml} / \mathrm{kg}$ berat badan ikan ternyata sudah kurang berpengaruh lagi terhadap daya tetas telur ini bisa dikarenakan oleh kelebihan dosis sehingga dapat memperlambat pergerakan dari spermatozoa dalam membuahi telur. Sedangkan tanpa menggunakan dosis ovaprim (0 $\mathrm{ml} / \mathrm{kg}$ berat badan ikan) juga kurang berpengaruh karena tidak adanya hormon perangsang yang diberikan. Ini berarti perlakuan $0,6 \mathrm{ml} / \mathrm{kg}$ berat badan ikan ovaprim pada ikan Patin siam yang digunakan sudah maksimum. Dengan demikian dikatakan bahwa pemberian hormon ovaprim 0,6 ml/kg berat badan ikan dapat meningkatkan daya tetas telur dengan rata - rata 80,86 \% dari hasil pemijahan.

Peningkatan daya tetas telur ikan Patin siam yang diberi larutan ovaprim menurut Manickam dan Joy (1989) disebabkan karena kandungan Folicle Stimulating Hormone (FSH) meningkat sehingga folikel berkembang dan daya tetas telur juga meningkat. Sedangkan menurut Murtidjo (2001), pelepasan sperma dan sel telur dalam waktu yang berbeda dan relatif 
singkat dapat berakibat pada kegagalan fertilisasi, hal ini dikarenakan sperma yang terkadang lamban dan cenderung tidak aktif bergerak sebab sperma berada dalam cairan plasma. Cairan plasma mempunyai konsentrasi yang tinggi terhadap cairan sperma sehingga dapat menghambat aktifitas sperma yaitu berkurangnya daya gerak dan akhirnya sperma sukar untuk menebus celah mikrofil sel telur.

Menurut Effendi (1997), telur-telur hasil pemijahan yang dibuahi selanjutnya berkembang menjadi embrio dan akhirnya menetas menjadi larva, sedangkan telur yang tidak dibuahi akan mati dan membusuk. Lama waktu perkembangan hingga telur menetas menjadi larva tergantung pada spesies ikan dan suhu. Semakin tinggi suhu air media penetasan telur maka waktu penetasan menjadi semakin singkat. Namun demikian, telur menghendaki suhu tertentu atau suhu optimal yang memberikan efisiensi pemanfaatan kuning telur yang maksimal. Untuk keperluan perkembangan digunakan energi yang berasal dari kuning telur dan butiran minyak. Oleh karena itu, kuning telur terus menyusut sejalan dengan perkembangan embrio, energi yang terdapat dalam kuning telur berpindah ke organ tubuh embrio. Embrio terus berkembang dan membesar sehingga rongga telur menjadi penuh dan tidak sanggup untuk mewadahinya, maka dengan kekuatan pukulan dari dalam oleh sirip pangkal ekor, cangkang telur pecah dan embrio lepas dari kungkungan menjadi larva, pada saat itulah telur menetas menjadi larva.

Telur membutuhkan oksigen untuk kelangsungan hidupnya. Oksigen masuk kedalam telur secara difusi melalui lapisan permukaan cangkang telur, oleh karena itu media penetasan telur harus memiliki kandungan oksigen yang melimpah yaitu > $5 \mathrm{mg} /$ liter (Murtidjo, 2001).

Menurut Effendi (1992), suhu air mempunyai arti penting bagi pertumbuhan organisme yang hidup diperairan karena banyak berpengaruh terhadap pertumbuhan organisme. Suhu dapat mempengaruhi berbagai aktifitas kehidupan dan berpengaruh terhadap oksigen terlarut didalam air, makin tinggi suhu makin rendah kelarutan oksigen didalam air. Salah satu faktor yang mempengaruhi lama waktu penetasan telur maupun tingkat penetasan telur adalah suhu, dimana semakin tinggi suhu air media penetasan maka waktu penetasan semakin singkat. Pengamatan suhu yang dilakukan selama penelitian adalah $27,9^{\circ} \mathrm{C}-30^{\circ} \mathrm{C}$ sedangkan hasil pengukuran suhu pada proses penetasan telur selama penelitian adalah $25^{\circ} \mathrm{C}-30^{\circ} \mathrm{C}$. Variasi nilai kisaran suhu dan persentase penetasan yang berbeda disebabkan oleh perubahan lingkungan atau cuaca setempat.

Hasil penelitian ini dikatakan bahwa pada perlakuan $0,6 \mathrm{ml} / \mathrm{kg}$ berat badan ikan dapat meningkatkan daya tetas telur sehingga mampu menekan tingkat mortalitas pada telur ikan patin.

\section{Sintasan larva}

Sintasan larva diperoleh dari selisih antara jumlah larva pada akhir penelitian dikali dengan $100 \%$ dan dibagi dengan jumlah larva pada awal penelitian. Perhitungan sintasan larva dilakukan dengan memelihara 100 ekor larva yang baru menetas 
Hasil perhitungan diatas menunjukkan bahwa persentase penetasan ikan Patin siam terbaik adalah pada perlakuan $\mathrm{C}$ dengan dosis $0,6 \mathrm{ml} / \mathrm{kg}$ berat badan ikan dengan rata - rata 83,33 \% , kemudian disusul perlakuan $\mathrm{B}$ dengan dosis 0,3 $\mathrm{ml} / \mathrm{kg}$ berat badan ikan dengan rata rata 52,16 \%, dan perlakuan A dengan dosis $0, \mathrm{ml} / \mathrm{kg}$ berat badan ikan adalah rata - rata 36,5 \%, sedangkan perlakuan D dengan dosis $0,9 \mathrm{ml} / \mathrm{kg}$ berat badan ikan dengan rata - rata 24,83 \% (Gambar 3).

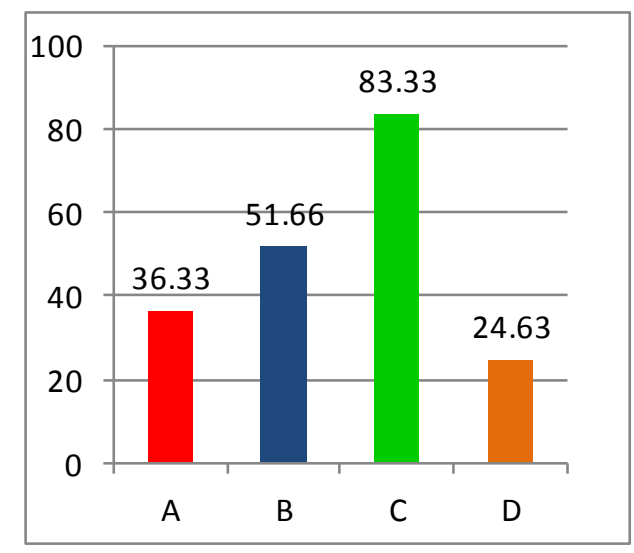

Perlakuan

Gambar 3. Sintasan larva ikan patin siam dengan perlakuan ovaprim dosis berbeda.

Berdasarkan analisis ragam diperoleh hasil bahwa perbedaan perlakuan dengan dosis ovaprim yang berbeda memberikan pengaruh yang sangat nyata terhadap perbedaan daya tetas telur ikan Patin siam.

Hasil analisis uji Beda Nyata Terkecil (BNT) yang diperoleh pada perlakuan 0,6 $\mathrm{ml} / \mathrm{kg}$ berat badan ikan menunjukkan perbedaan sangat nyata dengan perlakuan $0,3 \mathrm{ml} / \mathrm{kg}$ berat badan ikan, $0 \mathrm{ml} / \mathrm{kg}$ berat badan ikan dan 0,9 ml/kg berat badan ikan.
Dari hasil penelitian dapat dilihat bahwa pada dasarnya induk ikan yang disuntik dengan hormon ovaprim dan yang tidak disuntik akan memberikan pengaruh terhadap sintasan larva.

Induk ikan patin yang disuntik dengan hormon ovaprim dosis 0,6 ml/kg berat badan ikan menunjukkan hasil yang baik bagi sintasan larva patin. Tapi ketika dosis ovaprim diturunkan menjadi 0,3 $\mathrm{ml} / \mathrm{kg}$ berat badan ikan dan dinaikan menjadi 0,9 $\mathrm{ml} / \mathrm{kg}$ berat badan ikan dan tanpa perlakuan dosis ovaprim, ternyata menunjukkan hasil yang kurang berpengaruh lagi terhadap sintasan larva. Ini bisa dikarenakan ketidak cocokkan dosis ovaprim yang diberikan akibat kelebihan ataupun kekurangan ovaprim.

Hasil penelitian ini dikatakan bahwa pada perlakuan $\mathrm{C}(0,6 \mathrm{ml} / \mathrm{kg}$ berat badan ikan) ternyata dapat meningkatkan sintasan larva tertinggi dengan rata - rata 83,33\% dari hasil pemijahan. Ini berarti pemberian dosis ovaprim 0,3 $\mathrm{ml} / \mathrm{kg}$ berat badan ikan adalah dosis ovaprim yang terbaik bagi sintasan larva ikan patin.

Pengukuran kualitas air selama penelitian meliputi : suhu air, $\mathrm{pH}$, oksigen terlarut, karbondioksida bebas, amoniak, alkalinitas.adalah sebagai berikut kisaran suhu selama percobaan antara $27.9-30{ }^{\circ} \mathrm{C}$, $\mathrm{pH}$ air 5.70 - 7.52, oksigen terlarut 3.10 $5.48 \mathrm{mg} / \mathrm{l}$, Kualitas air ini masih dalam batas toleransi kehidupan larva Patin.

\section{KESIMPULAN}

Hormon ovaprim dapat mempengaruhi latensi waktu pemijahan, daya tetas telur dan sintasan larva ikan Patin Siam dengan dosis terbaik 0,6 ml/kg berat badan ikan. 


\section{DAFTAR PUSTAKA}

Amri K, Khairuman. 2008. Buku Pintar

Budidaya 15 Ikan Konsumsi.

Djarijah. 2001. Pembenihan Ikan Mas.

Penerbit Kanisius Yogyakarta. 111 hal.

Effendie MI. 1992. Metoda Biologi Perikanan. Penerbit Yayasan Agromedia Bogor.

Effendie MI. 1997. Biologi Perikanan. Yayasan Dewi Sri, Bogor.

Effrizal 1998. Respon Ovulasi Ikan Lele Dumbo (Clarias gariepinus B) Dari Berbagai Dosis Hormon LHRH-a, Fisheries Jurnal. Garing. Vol. 7 No.

2. Jurnal Fakultas Perikanan Universitas Bung Hatta. Padang.

Epler P. 1981. Effect of Steroid and Gonadotropin Hormone the Maturation of Carp Oocyte Maturation and Ovulation. Pol. Arch. Hidrobiol $28: 127$ - 133.

Ernawati Y. 1990. Penggunaan prostaglandin $\mathrm{F}_{2} \alpha\left(\mathrm{PGF}_{2} \alpha\right)$ Sebagai Induksi Ovulasi Ikan Lele Dumbo (Clarias gariepinus Burcheel). Tesis Magister Sains. Program Pascasarjana, IPB. Bogor.

Funjaya Y. 2004. Fisiologi Ikan. Jakarta, Rineka Cipta

Harker K. 1995. Pembiakan Kap dengan Menggunakan Ovaprim di India. Warta Akuakulture. Volume 2, No.3.

Lam TJ. 1985. Induced Spawning in Fish. In Lee CS and Liao IC (Eds). Reproduction and Culture at Milkfish the Oceanic Institute, Hawai.

Manickam P, Joy KP. 1989. Induction of
Maturation and Ovulation by Pimozide LHRH AnalogueTreatment and Resulting High pquality Fof Fa Pustaka : Jak Production in the Asian Catfish, Clarias batrachus L. Aquaculture 83 : 193 - 199.

Murtidjo BA. 2001. Beberapa Metode Pembenihan Ikan Air Tawar. Penerbit Kanisius, Yogyakarta.

Nandeesha MCKG, Rao R, Jayanna NC. Parker TJ, Varghese P. Keshavanath, Sheety HPC. 1990a. Induced spawning of Indian Mayor Carps Throught Single Aplication of Ovaprim. In : Hirano, R. and I. Hanyu (Eds). The $\mathrm{n}^{\text {nd }}$ Asian Fish. Forum, Asian Fisheries Society, Indian Branch. Mangalore, India.

Peter REHR, Lin CVD. 1988. Induceed Ovulation and Spawning of Cultured Freshwater Fish in China : Advenches in Aplication of GnRH Analogue and Dopamine antagonis. Aquaculture $74: 1-10$.

Steel RGD, Torrie JH, 1991. Prinsip Dasar dan Prosedur Statistika. PT. Gramedia. Jakarta.

Sukendi 1995. Pengaruh Kombinasi Penyuntikan Ovaprim dan Prostaglandin $\mathrm{F}_{2} \alpha$ Terhadap Daya rangsang Ovulasi dan Kualitas Telur Ikan Lele Dumbo (Clarias gariepinus Burcheel). Program Pascasarjana Institut Pertanian Bogor.

Woynarovich E, Horvarth. 1981. The Artificial Propagation of Warm Water Finfishes A Manual For Extension. FAO Technical Paper No. 201. FIR/T 201. 